\title{
CATALYST
}

feminism, theory, technoscience

\section{Resisting and Remaking Sex in the Petri Dish, the Clinic, and on the Track}

\author{
Madeleine Pape \\ University of Lausanne \\ madeleine.pape@unil.ch \\ Katrina Karkazis \\ Emory University \\ katrina.karkazis@emory.edu
}

J. R. Latham

Deakin University and University of Melbourne textual.gore@gmail.com

Stacey A. Ritz

McMaster University

ritzsa@mcmaster.ca

\section{Abstract}

Assemblages of sex are continuously being enacted by policymakers, scientists, and medical providers across a range of settings, resulting in multiple and often contradictory notions of what "sex" is and how it is expressed in the body. As feminist scholars have shown, such enactments are mutable yet resilient, often with the net effect of restricting how "sex" can emerge as a material dimension of 
our embodied, lived experiences. What happens when feminist scholars seek to intervene in order to promote more complex, entangled, dynamic, and just enactments of "sex" in policy and practice? This lab meeting gathers interdisciplinary scholars to reflect on their experiences of pursuing change in the laboratory, the gender clinic, and on the athletics track.

\section{Introduction}

Action is the call of the moment. This lab meeting, envisioned before the recent upwelling of organized resistance to anti-Black racism in the United States (U.S.) and elsewhere, takes action as its subject. For the three interdisciplinary scholars interviewed here, the focus of resistance is the institutionally entrenched enactment of "sex" as a presumed biological, binary, and rigid form of embodied difference-one asserted as capable of escaping the clutches of gender to exert its own independent effects on human (and nonhuman) bodies. Static and ahistorical, such enactments also conceal how sex as a categorical schema is coconstructed with ideologies of race and put to work in service of white and Western imperialism, a dynamic that Black feminist theorists in particular have brought to the fore (Bailey, 2016; Collins, 2004; Fausto-Sterling, 1995; Hammonds, 1997; Holloway, 2011; Magubane, 2014; Markowitz, 2001; Stepan, 1991).

As feminist scholars have frequently shown, sex does not precede but is enacted through the actions of its practitioners (Fausto-Sterling, 2000; Karkazis, 2008; Latham, 2019; Oudshoorn, 1994; Richardson, 2013; Ritz, 2017). The protagonists in our overlapping realms of research and activism are laboratory scientists, medical providers, and policymakers. Their collective practices bring sex into existence not merely as an assigned category but as an ontological entity that can be modeled in a petri dish or lab mouse, molded in the gender clinic to repatriate the trans body and establish the gender binary anew, or reduced to a single trait (e.g., testosterone) and then measured to regulate inclusion in international sports competitions (Jordan-Young \& Karkazis, 2019; Pape, 2019; Ritz, 2017). These multiple enactments of sex succeed in hanging together as an apparent whole only because of the singular ideology that underpins them (Latham, 2017b). The laboratory, medical clinic, and athletics track can each be considered a locus of practice in a larger interconnected landscape: spaces where sex comes to matter, materially and ideologically, in ways that are both local and specific yet also have far-reaching consequences. 
Practitioners must invest considerable time in defining what sex is, precisely because sex is not straightforward (Karkazis, 2019a). This complexity is not limited to intersex and trans embodiments: ever the "trickster" (Haraway, 1988, p. 593), sex in all its manifestations evades the imposition of a neat, binary frame. A prime example is the Sex as a Biological Variable (SABV) policy effort of the US National Institutes of Health (Clayton \& Collins, 2014). The mandate initially sought to require the use of both "female" and "male" models in cell-based research. In practice, this task has proven undoable because "sex" is not a stable, dichotomous property that follows cells from their source to the petri dish (Ritz, 2017; see also SABV policy discussion in Catalyst lab meeting Joel et al., 2015; Richardson et al., 2015).

The stakes are high, as evidenced by the decision of the US Department of Health and Human Services in June 2020 to reverse protections for transgender people established under the Affordable Care Act. The decision appeals to science in claiming that "sex" is a static, strict, and uncontroversial binary: "sex means a person's status as male or female based on immutable biological traits identifiable by or before birth" (Green et al., 2018; for critique see Nature, 2018). While contestation of such enactments is proliferating, the institutional response is frequently one of doubling down and mutation. In the case of sport, for example, the frontline has expanded from the Court of Arbitration for Sport in Lausanne, Switzerland, to local jurisdictions such as the State Legislature of Idaho in Boise, with "sex" assembled yet again in an effort to exclude trans people from sport (see CAS, 2015, 2019; Idaho State Legislature, 2020).

How can these indeterminate yet resilient enactments of sex be challenged to make room for more inclusive, dynamic, and complex understandings of "sex," including its entanglements with "gender" as well as ideologies of race and nation?

I convened this lab meeting as a researcher who repeatedly observes feminist technoscience scholars excluded from decision-making tables and denied expertise in moments when sex as an emergent ontological entity hangs in the balance (see for example Pape, 2019). As a sociologist who studies policy enactments of sex in biomedicine and sport, I invited cultural anthropologist Katrina Karkazis (Emory University, US), queer theorist J. R. Latham (Deakin University and University of Melbourne, Australia), and immunologist Stacey Ritz 
(McMaster University, Canada) to share what is common and distinct about their experiences of taking action to resist and reconfigure the systems that uphold oppressive ontologies of sex, and which do so always in intersection with the violent processes of capitalism and racialization that characterize the settler colonial societies in which each of us are embedded.

Madeleine: Could each of you say a little about your realms of action: where you're encountering enactments of sex and the kinds of activism or change efforts you've being pursuing?

Stacey: I come from a background as a biomedical scientist where I worked in labbased research for over fifteen years using animal models and cell cultures. As a grad student, I had a nascent feminist consciousness and was alert to the importance of thinking about sex and gender in that context. Although feminist theories and concepts around sex and gender were compelling and galvanizing for me, it was less clear how I should translate their nuances and complexities into the concrete context of the lab. I felt a real dissonance and disconnect there. Over the years I've moved away from the lab work itself and into the space of operationalizing sex in lab-based research as my main area of scholarly research, trying to bridge that gap. I'm also engaged with the policy shifts and directives from major funding agencies about what lab-based researchers should be doing to consider sex and gender. It is particularly concerning to me that sex and gender here have primarily been constructed around a female/male binary, taking for granted that this is a clear and important distinction. Researchers and policymakers also endorse an artificial separation of sex and gender, with the ensuing interpretation that if you're not using human subjects, you can just ignore gender.

Joe: I suppose I come to this work as a...patient? Sort of...Wow! I've never introduced myself as a "patient" before!... I guess because that's so discrediting, isn't it?

Katrina: What makes your work really powerful, Joe, but also potentially draining, is something I don't encounter. I write about clinical encounters as someone who's on the outside of those encounters, but in the clinic, the patient's multiple identities, roles, and knowledges can get flattened. You have both a patient perspective and a feminist STS lens, but I feel as though in that clinical moment, only one of those identities is elevated, and that is the patient identity. 
Joe: Thank you so much, Katrina. Yeah, it's not that I came to this work as a patient...I started my $\mathrm{PhD}$ researching trans sexualities, or trying to, and realizing that because of how medicine considers trans people-as being sick with the illness of hating one's own sex, a disorder that can be remedied via a package of medical interventions that produce a "complete sex change"--it followed that the sexual lives and healthcare needs of trans people were not only poorly understood, but were hardly even considered worthy of research. Doctors seemed to think that trans people don't have sex, by which I mean fucking, unless they have had genital surgery (and everything else) first. And that's simply not the case, obviously. But this way of thinking meant that all kinds of clinical research, especially on sexual health, just didn't exist. For instance, if you assume that trans men don't have sex, or don't have sex with other men, including men who are not trans, then you're missing an awful lot. I had to pivot my research to deal with that absence. So, I think about how "sex" and sexuality operate in practices of transgender medicine, how we understand sex more broadly because of how it is enacted by medicine, and how we might intervene to make these usually difficult, expensive, and prejudicial processes more just, accessible, and equitable.

Katrina: I came to academia because I wanted to solve problems in the world that I saw. Traditional academic analysis and writing is one tool for achieving what I want to do, but it can't be the only one. Over the past twenty years, I've focused on two areas where the harms are tied to the concept of sex: medical responses to intersex and sex testing in sport. I'm trying to disrupt how sedimented ideas about "sex" become institutionalized in systems with power, and how that sanctioning does violence to people, and how that violence can then in turn be obscured by medical and scientific authority to make truth claims.

Madeleine: What strategies have been effective for you?

Katrina: The first step is always the research and analysis to understand the issue, the arguments being made (and the assumptions about gender and bodies that undergird them), and the problems these raise for actual people. From there, and partnering with activists, I find ways to disseminate evidence and counterarguments and to exert pressure to change practices and policies, including writing op-eds, lobbying, convening, bringing court cases, testifying, presenting at grand rounds, and giving other talks. Earlier on my process was more ad hoc, but it's less opaque to me now; I feel like I have a more intuitive 
sense of what to do. The work behind the scenes is critical, but so is the media [see, for example, Jordan-Young \& Karkazis, 2012; Karkazis, 2019b \& 2019c]. I've spent a lot of time cultivating media relationships and talking to journalists and so much of this has happened via Twitter.

Stacey: Probably the moments where I have felt most effective are the opportunities to speak directly to lab scientists and offer some key examples where implementing a female/male binary fails to reflect crucial mechanisms within the phenomenon, or illustrating how gender is relevant to one's analytical and interpretive framework even if you're using experimental animals or cells. These are moments of dialogue where I can respond directly to the specific issues of concern or questions a scientist has. One of my favorite examples to use in these discussions is work by Karen Messing investigating a gender disparity in shoulder injury amongst [diesel] mechanics, which found that the issue wasn't sex so much as height [Courville et al., 1991]. Shorter mechanics were at risk. Women were overrepresented amongst those with shoulder injuries because they are shorter on average. Any intervention based on sex would have missed the point entirely and put shorter men at risk.

Joe: I might have to get back to you on that one...[laughs]. I suppose you might say I have inserted myself into medical discussions that exclude both feminist analysis and patient experiences...[see Latham, 2017a].

Madeleine: Policymakers and stakeholders frequently appear unreceptive to the notion that recognizing the complexity of "sex" can in fact advance gender equity, rather than undermine it. How have you encountered this issue and how do you make sense of it?

Stacey: A number of years ago I had an encounter with a pretty prominent scholar of STS where I was making the argument that there is no "male" HeLa cell, there is no "female" A549 cell, and there never will be in a meaningful way. This scholar put to me, "If you're only studying this 'male' A549 cell, aren't you ignoring women?" and sort of challenging me, suggesting implicitly that I was anti-feminist by resisting this. I wasn't able to formulate a good answer in the moment, but it prompted a lot of deliberation. In hindsight I was able to articulate that one single cell line doesn't represent "men" either: they are cells from one person's body, cultured under artificial conditions for decades. Cultured cells in vitro, especially transformed cell lines, are never going to be good models for "sex" or "gender," 
and like all model systems, we have to be alert to their limitations [Ritz, 2017]. Katrina: Sorry to do this, but someone like J. K. Rowling hears what you just said about sex, Stacey, which is something that I would say as well, and thinks we're saying that sex isn't "real." This is not what we are saying, but this is how it is interpreted, perhaps opportunistically. A key challenge is how to communicate what is evident to us as gender theorists or feminist STS scholars in a way that penetrates and shifts these stale debates. Someone recently dismissed my work by saying that I am not a good scholar, which is disingenuous because they didn't even engage with my ideas, but this is what we're up against: the idea that we're saying sex isn't real when what we're doing is drawing on theory and science to complicate ideas about sex; that our work is shoddy for challenging commonsense ideas; and that we're anti-feminist, or anti-woman for doing so, none of which are true.

Joe: [Sighs] Indeed. I think a part of our challenge is that, in our critiques, people feel as though we are undermining their very sense of themselves. Sex is a fundamental way we understand who we are. For instance, I know that my mere presence can be confronting for nontrans men. I see it. I can shake their very core sense of themselves as men. It is impossible to have a "rational" conversation about the complexities of sex with someone who feels like that: they feel attacked, they get defensive, and we see that play out over and over again.

Madeleine: And that raises the question of who is recognized as having legitimate expertise in these spaces, and how feminist scholars who do engaged work can do so without compromising their ability to be recognized as a legitimate voice in policy debates, especially in spaces that still privilege the kind of disembodied objectivity that feminist scholars have long been challenging.

Katrina: For me, feminist practice in academia requires an ethics of engagement. I do the advocacy work because I owe it to the people who have shared the most vulnerable and painful experiences of their lives with me. But advocacy is seen by those in power as undermining your objectivity, your authority, your scholarly commitment. So, the advocacy I do can diminish my authority in the venues and circumstances where I need it most, such as court cases. Critics use the "activist" label opportunistically to discredit my work and my ideas. There are benefits to having a public face, because that's part of changing minds out in the world, but it's also risky because of how it can be used against me. Overall, though, it's been more beneficial than harmful. 
Joe: I'm thinking of the clinical aspect of your work, Katrina, going to talk in hospitals and being the scholar alongside intersex activists. And I think that is one of my frustrations: I don't get that authority. To clinicians and health professionals, rarely am I ever recognized as something other than a patient activist and, often, a disgruntled one. Or else a curiosity.

Madeleine: What about other costs that come with seeking to resist and change how practitioners enact sex? How do you find ways to endure this work?

Joe: Thinking about the toll that our research takes is something that we, as feminist scholars, tend to do, and I know that all of us here do that seriously. I did so much of my work because of what happened to me as a patient, because of all of the sexism that I encountered, which at the time astounded me [laughs]. As a scholar I have returned over and over again to those encounters, not only my own but a host of other people's representations of these experiences as well. This is difficult work. There is so much pain, and I mean pain not from "Gender Dysphoria" but from these processes. And to read all of the objectifying, dehumanizing, misguided ways that trans people are portrayed in medical texts was excruciating. But that was what I needed to do in order to try to understand how trans people's experiences of sex and gender and sexuality are constituted as an impairment to be corrected, a disorder that can be diagnosed and treated, resulting in a system that does people harm.

Stacey: It's emotional work, right? Trying to get people to care about something that they don't care about is emotional work. I mean, for me the core of it is trying to put this issue in terms that make people care about it.

Joe: Right, trying to make people care is so hard. And being critical of processes of "care" and challenging institutions like medicine-which is like sex in that people often feel incredibly attached to it as it relates to their own personal experience, which in the case of medicine may well be a life-saving intervention-is also really difficult but crucial to do. I try to encourage people to think about what constitutes good care, for whom, and how. Madi, your question about the imperative of enduring is really important for feminist STS to take on. In my book, I write about the ethical imperative and responsibility that people like me, who get called "college-educated whites" in US politics, have in engaging with medical practice. As someone who went through these processes with an awful lot going 
in my favor, I was confronted by how obscenely difficult and confusing it was for me. That's what motivated me to go back and meticulously analyze how sex was enacted along my treatment trajectory in order to show the host of contradictions, clashes, and hypocrisies that emerge in the clinic [Latham, 2017b]. If this is what it was like for me, a well-educated white person in a place that has a good healthcare system, then it doesn't make sense to talk about what is going on here as a "barrier," as it is so often described. For many people it's not a barrier: it's not even a possibility.

Katrina: Recently, the most consuming piece of my work has been bringing these court cases to the Court of Arbitration for Sport. When we did the first case for Dutee Chand, it was basically a full-time job for a year among a small group of people, including Dutee's lawyers, Bruce Kidd, and Payoshni Mitra. With the court cases, it's not just the time in the courtroom-it's everything leading up to and following that moment. And it is exhausting and draining. It would have been enough to just do that work, but as an academic you also have all of these other commitments. One of the reasons I have shifted my work over time is precisely because of that exhaustion. After ten or so years working in intersex rights, to have doctors come back with the same arguments that I feel I dismantled ten years earlier is frustrating [Karkazis, 2008]. Oftentimes you hit an incredible wall of resistance. So, you try to use this angle, explain it this way, put it in this forum, say it that way. And eventually, I tire. I also get intellectually bored because I don't want to keep saying the same things. The way I survive it is through community, like what we have here, with scholars, activists, lawyers, and others. That's why I have developed such abiding relationships with the people I work with. This is our linked-arm support system to keep fighting.

Stacey: I think one of the things that fills my tank and gives me the energy and the enthusiasm for doing this work is to look higher up in the pipeline and do the education and the teaching around sex and gender to undergraduates and trainees, so that hopefully ten years from now we don't have to argue with them about these same things again. I run a second-year undergraduate course on sex, gender, and health, and one of the most rewarding things for me is to grade their benchmarking activities and reflections at the end of term and feel like I've been able to disrupt some of their problematic socialization and open them up to being more critical about sex and gender. These students are going to be the next generation of researchers, healthcare providers, policymakers, and so on. Teaching makes me feel like I'm contributing to the pipeline of future scientists 
and not just dealing with the symptoms of the problem.

Madeleine: Katrina, you mentioned resistance and I want to pick up on that. What are some other forms of resistance that you all have encountered in your efforts to change how practitioners are enacting sex?

Katrina: With testosterone, as with sex, everybody thinks they understand what the object under discussion is. And that is a key hurdle or even the key hurdle: this idea that you actually don't require any specialized knowledge to understand what sex or testosterone is and is not, and what it does or does not do. A large part of what I argue is that multiple kinds of knowledges-not just biological and not just theoretical-are required when thinking about "sex." You have to think about epistemology, ontology, power, gender, race, class, and more. All of these come into play and make "sex" contextual, complex, and multiple, rather than straightforward, singular, and definitive.

Joe: Turning back to Stacey's point about "contributing to the pipeline" and making space for our work to go on, that's a scholar's dream, right? Yet so much of how the university industrial complex currently operates makes that dream hard to realize. I'm incredibly moved by the testimonies of readers and students who tell me that my work has made a difference to them. Yet the precarity key to academic capitalism makes it impossible to develop ongoing relationships. It remains especially hard for people who aren't white male scientists or doctors to impact these systems. And this is a really important question for feminist STS: How can we make it possible, practically, to take this work further? "Feminist STS" tends not to have the institutional support of a department, and these are critical material restrictions on what we're able to do. I mean, the conditions of the academic labor market are probably the biggest resistance to junior scholars doing this work, or trying to, frankly.

Stacey: One of the areas of resistance I encounter most often is people who are quite sympathetic and say, "Okay, yes, sex is more complex and dynamic than maybe we initially recognized, but that's too complicated for people to understand and for us to implement. We need to keep it simple otherwise no one will do anything." And my response to that is, "Well, 'simple' is one thing, but 'simplistic' doesn't take us where we want to go." There's no point to doing this work in a way that's actually counter to the questions of real inclusion and equity and trying to improve people's health. If you're not going to take the complexity 
of sex seriously, and instead you simplify it to get buy-in or to be feasible, then the kinds of answers we get at the other end are going to be deeply compromised. I also hear a lot of people who will say, "I'm only working in cells, so gender isn't relevant." Well, I disagree so strongly. You might not be able to put gender in your petri dish, but gender is absolutely relevant to your thinking.

Joe: It's already there!

Stacey: Right, it's shaped the approach that you took in the first place to even get to the point of plating your cells in that dish. And if you claim that it's irrelevant because you're working in cells, you've missed important opportunities for understanding what it is you're doing, how you interpret it, and how you translate that work to other audiences.

Katrina: Beck [Rebecca Jordan-Young] and I came up with the idea of "opportunistic epistemology" in our research on testosterone [Jordan-Young \& Karkazis, 2019]. It's when researchers reverse engineer the scientific process by starting with a particular outcome or conclusion and then crafting a "scientific" approach that is guaranteed to support their specific goal. In the case of sport, it was a desire to exclude some women athletes with naturally high testosterone from the women's category. At first, we thought the flatly differing accounts and disagreements about testosterone's role in athleticism stemmed from different disciplinary approaches. But we quickly figured out that policy supporters were constructing and conjuring evidence in order to support their policy goal. And that's very different, I think, to what Stacey's talking about where people might not recognize how their pre-theoretical predilections shape their research questions and practices. Something we need to consider is: When are these moments of genuine disagreement over the ontology of sex, and when is it really a political tactic, designed to limit people's participation in social life and deny them the rights and privileges that other people have?

Madeleine: Where do you see the openings, or perhaps the seeds or possibilities of change?

Joe: I suppose I would say that while as a scholar or activist we can be put in this political position of the disgruntled patient, which is undermining, when you are a patient in a room with your doctor, there are ways to intervene. Doctors-good doctors-listen to their patients and care about helping them. Doctors don't 
change their practice because there's a new version of the DSM: they learn from interacting with their patients, from our questions and concerns and reactions. And this can be a real burden and an obstacle to healthcare. But it can also be an opportunity to intervene. And you don't have to "be trans" to impact these systems, either [see Heyes \& Latham 2019].

Stacey: I'm working on disrupting sex as a female/male binary for biomedical researchers by taking sex apart and documenting how complex and heterogeneous it is, but it's the dynamism of sex that I'm probably most excited about right now. We can talk about all the different components that go into this construct of sex, which is important work, but what really fires me at the moment is this recognition that very little of that is static or stable: it's constantly changing in response to the environment, social inputs, and changes across the life course. It raises all kinds of exciting scientific questions, like what do we ask scientists to do with that when they're planning an experiment? The power of an experiment hinges on its ability to simplify and control, yet so many of these dynamic, fluid, and responsive aspects of sex are impossible to control. What does that mean when we're trying to use the power of the experiment to develop a better understanding of how our biology works and how that translates into health outcomes? It's incredibly challenging and I find it really hard to envision what that could look like, but I'm also really excited about what might be possible in this space.

Joe: It can also be hopeful to consider that we're in a moment in which there is real structural upheaval in how people are thinking about these problems. As I'm thinking about how sex and power are enacted, right now I'm thinking about police brutality, I'm thinking about the assassinations of Malcolm X and Martin Luther King Jr., and the Royal Commission into Aboriginal Deaths in Custody in Australia [see Deaths Inside, 2020]. I'm thinking about all the people I know who've died. I'm thinking about state power and its upheaval. People are talking about this hugely powerful institution, the police, having its resources put elsewhere. This movement makes it possible to think about how other powerful institutions are heavily resourced in ways that prop up white supremacy, like medicine and science.

Madeleine: And, Joe, that raises a really critical question, which is how can we think through the co-constitution of race, nation, and sex in our work? 
Stacey: I initially came to this work entirely focused on sex/gender, but the significance of race, socioeconomic status, culture, and other intersectional factors can't be ignored. Conceptually, these relationships feel clearer to me at the level of clinical research and human subjects, but I'll admit that I'm challenged to envision a critical, defensible way to translate that into work with experimental animals and cells that doesn't diminish, demean, or deny the political and social realities of oppression and marginalization. Hankivsky and colleagues' paper on bringing intersectionality to biomedical research has been helpful, though how it should inform nonhuman lab work is less clear to me right now [Hankivsky et al., 2017].

Katrina: One of my disappointments in my first book on intersex is how little I interrogated race as an analytical category, even though I was aware of its imbrication with sex/gender. Race very often slips out of the frame and yet, ironically, the whole understanding of binary sex stems from racial hierarchies and ideologies. Too often, I see discussions of sex and sex dimorphism that don't take into account how sex/gender is racialized, even though the development of these concepts-and ideologies of sex/gender difference-are inextricably linked to racial ideologies. The challenge is to deal very seriously with how this becomes possible and to correct it. This came up in the context of my work on sex testing, where if you talk to people-scientists, sports policymakers, athletes-race was dismissed as irrelevant even though nearly all of the women who are tested are Black and Brown women from the Global South. But trying to show how raceand place-operated in these regulations when policy supporters claimed that race was not implicated was incredibly difficult. We [Rebecca Jordan-Young and I] call it a "ghost variable" and have sought to develop a methodology to make race visible in claims devoid of explicit racial content. ${ }^{1}$ We cannot think about sex/gender without thinking about its imbrication with racial hierarchies. I say this as a challenge to myself that stems from my disappointment in my earlier work and that I'm trying to make sure I don't repeat.

Joe: Right, and revisiting one's prior work, especially its disappointments, is so important, rather than holding on to or pretending that we stand by everything we've ever said, as some people and disciplines tend to do. One of the things that feminist STS has to offer is an invitation to re-think, to re-turn, to re-consider our own work [Barad, 2014]. And that is a critical undertaking, not least because the refusal to question what we know-or what we think we know--is one of the most powerful ways that white supremacy sustains itself. 


\section{Notes}

${ }^{1}$ Karkazis and Jordan-Young's (2018) analysis of race and nation in the regulation of female athlete eligibility led to a special issue in Science, Technology \& Human Values (see Jordan-Young \& Karkazis, 2020).

\section{References}

Bailey, M. (2016). Misogynoir in medical media: On Caster Semenya and R. Kelly. Catalyst: Feminism, Theory, Technoscience, 2(2), 1-31.

https://doi.org/10.28g68/cftt.v2i2.28800

Barad, K. (2014). Diffracting diffraction: Cutting together-apart. Parallax, 20(3), 168187.

Clayton, J. A., \& Collins, F. S. (2014). Policy: NIH to balance sex in cell and animal studies. Nature, 509(7500), 282-283.

Collins, P. H. (2004). Black sexual politics: African Americans, gender, and the new racism. Routledge.

Court of Arbitration for Sport (CAS). (2015). CAS2014/A/3759 Dutee Chand v. Athletics Federation of India (AFI) \& the International Association of Athletics Federations (IAAF). Lausanne, Switzerland: Court of Arbitration for Sport. http://www.tascas.org/fileadmin/user upload/award internet.pdf

Court of Arbitration for Sport (CAS). (2019). CAS 2018/0/5794 Caster Semenya v. International Association of Athletics Federations. Athletics South Africa v. International Association of Athletics Federations. Lausanne, Switzerland: Court of Arbitration for Sport. https://www.tas-cas.org/fileadmin/user upload/CAS Award - redacted_Semenya ASA IAAF.pdf

Courville, J., Vézina, N., \& Messing, K. (1991). Comparison of the work activity of two mechanics: A woman and a man. International Journal of Industrial Ergonomics, 7, 163174 .

Deaths Inside. (2020). Deaths inside: Indigenous Australian deaths in custody [Database]. The Guardian. https://www.theguardian.com/australianews/series/deaths-inside

Fausto-Sterling, A. (1995). Gender, race, and nation: The comparative anatomy of 'Hottentot' women in Europe, 1815-1817. In J. Terry \& J. Urla (Eds.) Deviant bodies: Critical perspectives on difference in science and popular culture (pp. 19-48). Indiana University Press. 
Fausto-Sterling, A. (2000). Sexing the body: Gender politics and the construction of sexuality. Basic Books.

Green, E. L., Benner, K., \& Pear, R. (2018, October 21). "Transgender" could be defined out of existence under Trump administration. The New York Times.

Hammonds, E. M. (1997). Toward a genealogy of Black female sexuality: The problematic of silence. In M. J. Alexander \& C. T. Mohanty (Eds.), Feminist genealogies, colonial legacies, democratic futures (pp. 170-182). Routledge.

Hankivsky, O., Doyal, L., Einstein, G., Kelly, U., Shim, J., Weber, L., \& Repta, R. (2017). The odd couple: Using biomedical and intersectional approaches to address health inequities. Global Health Action, 10(sup2), 1326686.

Haraway, D. (1988). Situated knowledges: The science question in feminism and the privilege of partial perspective. Feminist Studies, 14(3), 575-599.

Heyes, C. J., \& Latham, J. R. (2018). Trans surgeries and cosmetic surgeries: The politics of analogy. TSO Transgender Studies Quarterly, 5(2), 174-189

Holloway, K. F. C. (2011). Private bodies, public texts: Race, gender, and a cultural bioethics. Duke University Press.

Idaho State Legislature. (2020). House Bill No. 500. Fairness in Women's Sport Act. https://legislature.idaho.gov/wpcontent/uploads/sessioninfo/2020/legislation/H0500.pdf

Joel, D., Kaiser, A., Richardson, S. S., Ritz, A. A., Roy, D., \& Subramaniam, B. (2015). A discussion on experiments and experimentation: NIH to balance sex in cell and animal research. Catalyst: Feminism, Theory, Technoscience, 1(1), 1-12.

https://doi.org/10.28g68/cftt.v1i1.28821

Jordan-Young, R., \& Karkazis, K. (2012, June 17). You say you're a woman? That should be enough. The New York Times.

https://www.nytimes.com/2012/06/18/sports/olympics/olympic-sex-verification-yousay-youre-a-woman-that-should-be-enough.html

Jordan-Young, R., \& Karkazis, K. (2019). Testosterone: An unauthorized biography. Harvard University Press.

Jordan-Young, R., \& Karkazis, K. (2020). Sensing race as a ghost variable in science, technology, and medicine. Science, Technology \& Human Values, 45(5), 763-778.

Karkazis, K. (2008). Fixing sex: Intersex, medical authority, and lived experience. Duke University Press. 
Karkazis, K. (2019a). The misuses of biological sex. The Lancet, 394(10212), 18981899.

Karkazis, K. (2019b, March 6). Stop talking about testosterone-there's no such thing as a "true sex." The Guardian.

https://www.theguardian.com/commentisfree/2019/mar/06/testosterone-biologicalsex-sports-bodies

Karkazis, K. (2019c, December 7). Interview: You can't use testosterone levels to divide people into male or female. The Guardian.

https://www.theguardian.com/science/2019/dec/07/katrina-karkazis-cannot-usetestosterone-divide-people-male-female-gender-aggression-sexual-function

Karkazis, K., \& Jordan-Young, R. (2018). The powers of testosterone: Obscuring race and regional bias in the regulation of women athletes. Feminist Formations, 30(2), 139.

Latham, J. R. (2017a). Making and treating trans problems: The ontological politics of clinical practices. Studies in Gender and Sexuality, 18(1), 40-61.

Latham, J. R. (2017b). (Re)Making sex: A praxiography of the gender clinic. Feminist Theory, 18(2), 177-204.

Latham, J. R. (2019). Axiomatic: Constituting "transexuality" and trans sexualities in medicine. Sexualities, 22(1-2), 13-30.

Magubane, Z. (2014). Spectacles and scholarship: Caster Semenya, intersex studies, and the problem of race in feminist theory. Signs, 39(3), 761-785.

Markowitz, S. (2001). Pelvic politics: Sexual dimorphism and racial difference. Signs, 26(2), 389-414.

Nature (editorial). (2018, November). Anatomy does not define gender. Nature, 563(7729), 5 .

Oudshoorn, N. (1994). Beyond the natural body: An archaeology of sex hormones Routledge.

Pape, M. (2019). Expertise and non-binary bodies: Sex, gender and the case of Dutee Chand. Body \& Society, 25(4), 3-28.

Richardson, S. (2013). Sex itself: The search for male and female in the human genome. University of Chicago Press.

Richardson, S., Reiches, M., Shattuck-Heidorn, H., LaBonte, M.L., \& Consoli, T. (2015). Opinion: Focus on sex differences will not address women's and men's health disparities. PNAS, 112(44), 13419-13420. 
Ritz, S. A. (2017). Complexities of addressing sex in cell culture research. Signs, 42(2), 307-327.

Stepan, N. L. (1991). The hour of eugenics: Race, gender, and nation in Latin America. Cornell University Press.

\section{Author Bios}

Madeleine Pape is currently a postdoctoral researcher at the University of Lausanne having completed her PhD in sociology at the University of Wisconsin-Madison in 2019. Pape examines how debates over "sex differences" arise as part of gender equity projects in sport and biomedicine, with particular attention to disagreement over the nature of sex, its relationship to gender, and its relevance to women's experiences in sport and health. Pape competed for Australia in the women's 8oom (Athletics) at the 2008 Olympic Games and 2009 World Championships.

Katrina Karkazis is a cultural anthropologist who examines medicoscientific understandings of sex/gender, sexuality, and the body to link several domains of inquiry: human biology, the social construction of knowledge, and relations of power. Across two prior books - Fixing Sex: Intersex, Medical Authority, and Lived Experience (Duke University Press, 2008), and Testosterone: An Unauthorized Biography (Harvard University Press, 2019)-as well as numerous articles, she has examined the medical treatment of intersex infants, "sex testing" of elite female athletes, and contemporary research on testosterone. She is currently working on an ethnography of "sex" as a category.

J. R. Latham is Alfred Deakin Postdoctoral Research Fellow at Deakin University and Honorary Fellow in Cultural Studies at the University of Melbourne, Australia. He is a social scientist and feminist theorist who specializes in the study of health and illness, combining critical concepts of "drugs," aging, and narrative with bioethics, queer theory, and science and technology studies. His first book, Making Maleness: Trans Men and the Politics of Medicine, is under contract with the University of Minnesota Press.

Stacey A. Ritz is an Associate Professor in the Department of Pathology and Molecular Medicine and assistant dean of the Bachelor of Health Sciences (Honours) Program at McMaster University. Her scholarly work focuses on how laboratorybased, experimental biomedical researchers can most effectively and appropriately account for gender and sex. This work is informed by her training as an experimental 
immunologist working in mouse models and cell culture, along with feminist science studies and other critical perspectives on scientific practice. She aims to make these discourses legible across these disciplines, and to develop channels through which the methods and epistemologies of biomedical research can be deployed to better serve gender equity in health. 